\title{
WORKSHOP PROGRAMMING AS A PART OF TECHNOLOGICAL PREPARATION OF PRODUCTION
}

\author{
Tomáš Dodok ${ }^{1}$, Nadežda Čuboňová', Ivan Kuric ${ }^{1}$ \\ 1 Faculty of Mechanical Engineering, Department of Automation and Production Systems, University of Žilina, \\ Univerzitná 1, 01026 Žilina, Slovak Republic, e-mail: tomas.dodok@fstroj.uniza.sk, nadezda.cubonova@ \\ fstroj.uniza.sk, ivan.kuric@fstroj.uniza.sk
}

Received: 2016.12.15

Accepted: 2017.02.01

Published: 2017.03.01

\begin{abstract}
The article deals with the application of workshop programing system - Sinumerik Operate $840 \mathrm{D}$ SL in technological preparation of production. Application of the system in real situation pointed out on several problems and disadvantages of the system. The article contains a comparison of the effectiveness between workshop programming, ISO programming, and CAM system programming. Sinumerik Operate was used as a control system at a milling machine EMCO Concept Mill 105.
\end{abstract}

Keywords: Sinumerik Operate 840D SL, workshop programing, EMCO machine tool.

\section{INTRODUCTION}

At present, three types of programming methods are used to develop NC programs, ISO programming, workshop programming and CAM programming. All these types impose requirements for operators at a machine or programmers in the CAM system. Writing a program manually requires a good knowledge of the ISO code. For complicated shapes CAM system can be used, but the programmer must know how to work with a chosen system. Workshop programing allows to create NC programs for complex but simple components. Workshop programing is also called "conversational programming" [1-4].

After a purchase of Sinumerik Operate 840D SL control system applying this system for machine tool EMCO Concept Mill 105 was necessary. This machine tool is used for teaching in Laboratory of Machine Tools Programming Department of Automation and Production Systems (DAPS). The article deals with the application of workshop programming in manufacturing process. The solution includes verification of the control system Sinumerik Operate 840D SL for the production of components through experimental components. Part of verification is also a comparison of the effectiveness of the use of this method for creation of NC programs [5-8].

\section{DESCRIPTION OF EQUIQMENT MACHINE TOOL}

Machine EMCO Concept MILL 105 (Fig. $1 \mathrm{~A})$ is a training machine designed to teach programming and operation of CNC machines. The tool change is done by a tool turret equipped with 10 stations. The work area allows to use a work piece with dimensions in X-axis $200 \mathrm{~mm}$, in Yaxis $150 \mathrm{~mm}$, effective height of $Z$ axis is 150 $\mathrm{mm}$. The machine tool can be controlled by several control systems, e.g. Sinumerik 810D/840D, Heidenhain TNC 426/430, Sinumerik Operate 840D SL and others. WinNC serves like host for emulation control systems and allows to install up to nine control system. All systems are controlled with interchangeable control panels (Fig. 1B) and control keyboards [8-11].

\section{INTERCHANGEABLE CONTROL PANEL}

Interchangeable control panel (Fig. 1B) allows user to change the control keyboards accord- 

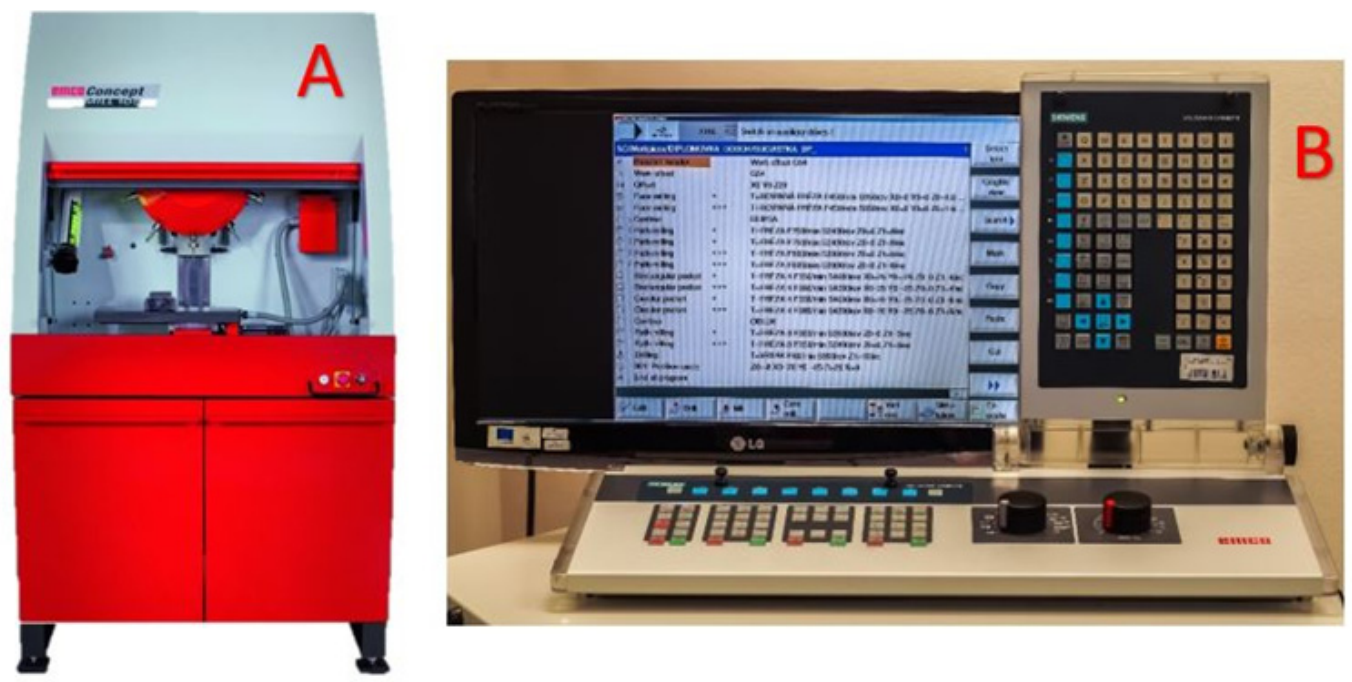

Fig. 1. EMCO Concept Mill 105 and interchangeable control panel

ing to the selected control system. Change can be made quickly and it takes only a few seconds. Interchangeable panel can be connected to any Concept machine or PC. In Figure 2 all control keyboard owned by Department of Automation and Production Systems are shown, A - Heidenhain TNC 426/430, B - Sinumerik 840D, C - Sinumerik Operate 840D SL. Each keyboard has specific layout and keys with specific functions.

\section{WORKSHOP PROGRAMMING}

Workshop programming allows users to easily program complex components, even without knowledge of ISO codes. This type of programming is encountered mainly for lathes and milling machines. It is most suitable for a wide range of components with simple shapes in pieces or small series production.

Basic features and characteristics workshop programming can be separate into several groups:

- Efficiency and intuitiveness - dialogue between operator and system,

- User friendly interface - inputs fields including animated elements,

- Simulation of the machining process - simulation of the machining process, toolpath and collision between tool and work piece.

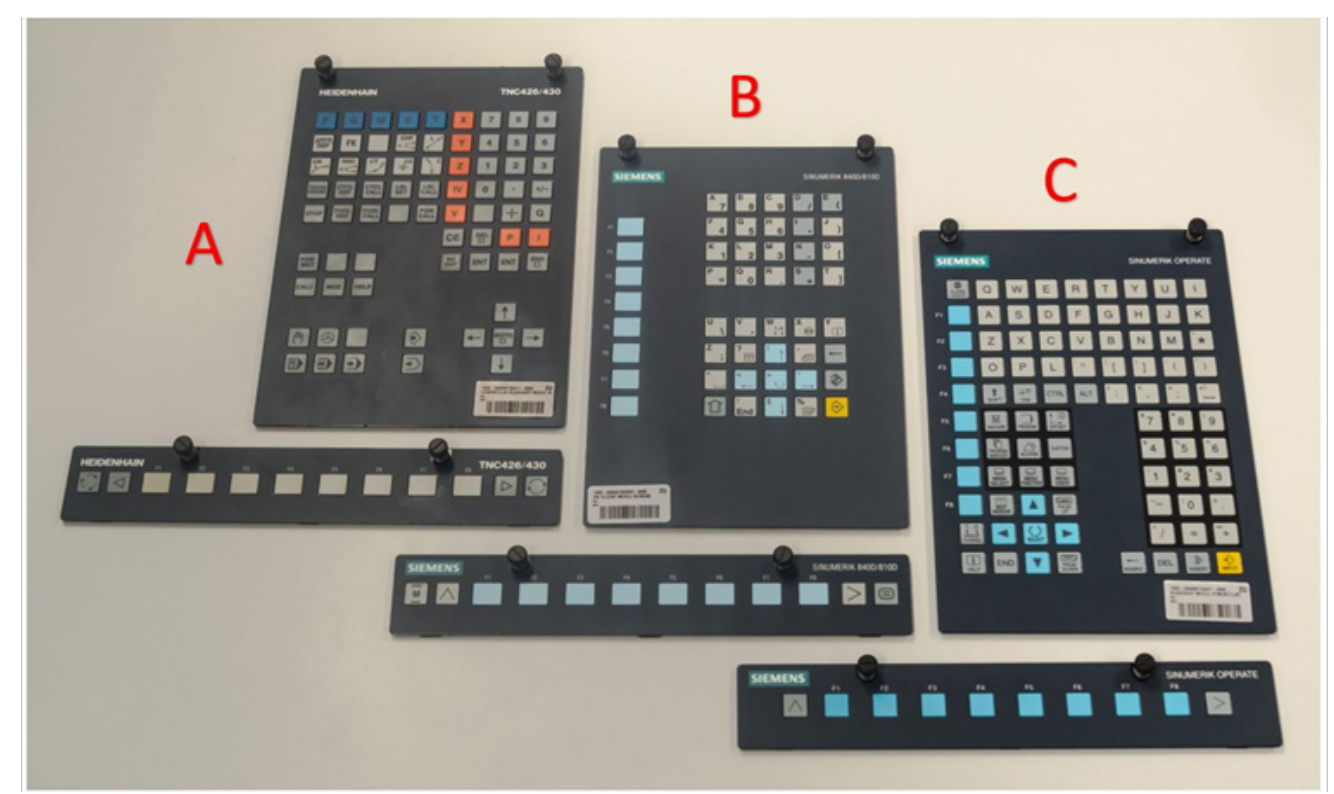

Fig. 2. Control keyboards for interchangeable control panel 


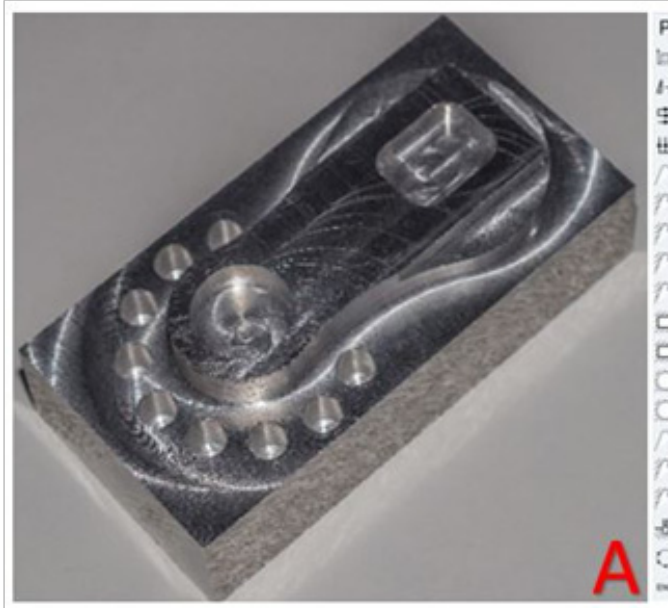

Program header
Work offset
Oftset
Face milling
Face milling
Contour
Path milling
Path milling
i Path milling
Path milling
Rectangular pocket
Rectangular pocket
Circular pocket
Circular pocket
Contour
Path milling
Path milling
Drilling
001: Position circle
End of program

\begin{tabular}{|c|}
\hline Work oftset G54 \\
\hline G54 \\
\hline$x_{0}$ Yo ZZ21 \\
\hline T=ROVINNÁ FRÉZZA F450/min S950rev X0=0 Y0=0 Z0=1.6 ... \\
\hline T=ROVINNÁ FRÉZZA F450/min S950rev X0=0 Y0=0 Z0=1.6 ... \\
\hline EUPSA \\
\hline T=FRÉZA F750/min S2400rev Z0-0 Z1-8inc \\
\hline $\mathrm{T}=F R E Z Z A F 750 / \mathrm{min} S 2400 \mathrm{rev} \mathrm{Z0}=0 \mathrm{Z1}=8 \mathrm{inc}$ \\
\hline 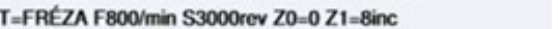 \\
\hline $\mathrm{T}=F R E Z Z A$ F800/min S3000rev Z0=0 Z1=8inc \\
\hline$T=F R E Z Z A$ F350/min $S 4000 \mathrm{rev} X_{0}=25$ Y0=-25 Z0=0 Z1=4inc \\
\hline$T=F R E ́ Z Z A$ F380/min $S 4300 \mathrm{rev} X 0=25$ Y0=-25 Z0=0 Z1 =4inc \\
\hline $\mathrm{T}=F R E Z Z A 4 \mathrm{~F} 350 / \mathrm{min} S 4000 \mathrm{rev} \mathrm{X0}=70 \mathrm{YO}=-25 \mathrm{Z0}=0 \mathrm{Z1}=6$ inc \\
\hline T=FRÉZZA 4 F380/min S4300rev X0=70 Y0=-25 Z0=0 Z1=6inc \\
\hline OBLUK \\
\hline$T=F R E Z Z A$ B F300/min S3500rev Z0=0 Z1=3inc \\
\hline$T=F R E ́ Z A$ 8 F350/min $S 3800$ rev $Z 0=0 Z 1=3$ inc \\
\hline T=VRTÁK F60/min S900rev Z1=10inc \\
\hline$Z 0=-8 \times 0=70$ YO $=-25$ R $=20 \mathrm{~N}=9$ \\
\hline
\end{tabular}

Fig. 3. First component and NC program in Sinumerik Operate 840D

\section{APPLICATION AND VERIFICATION OF WORKSHOP PROGRAMMING AT EXPERIMENTAL MILLED PART PRODUCTION}

For verification of Sinumerik Operate 840D SL was used a group of components with similar shapes. From this group were selected three components for further experimentation - component no. $1,2,3$. The experimental components were designed to verify the accuracy and effectiveness of using different cycles in their production. The main purpose of verification was to verify functionality of the available cycles.

The first component (Fig. 3A) represents a group of components which use more machining cycles, e.g. the cycles for machining spigots, pockets and drilling holes. Geometric properties of pockets are entered inside of the cycles. There is no need to define a contour of pockets. In Fig- ure $3 \mathrm{~B}$ is shown the $\mathrm{NC}$ program with all cycles. The second type of component (Fig. 4A) includes machining cycle for pocket and drilling. Manufacturing process was created in order to verify the functionality of both cycles. In Figure $4 \mathrm{~B}$ is shown machining cycles for pockets with defining dimensions of pocket. The third type of component (Fig. 5A) contains different cycle for machining pocket. This cycle requires the definition of contour and it was verified in the production of circular spigots. In Figure 5A is shown in NC program with defined contour for milling of spigots.

All experimental components contain cycles for drilling holes. Patterns of holes are different e.g. on first component a circular pattern was used, On second and third components square and rectangular patterns were used. The experimental components were created by using workshop programming Sinumerik Operate 840D SL. They were further used to compare the efficiency
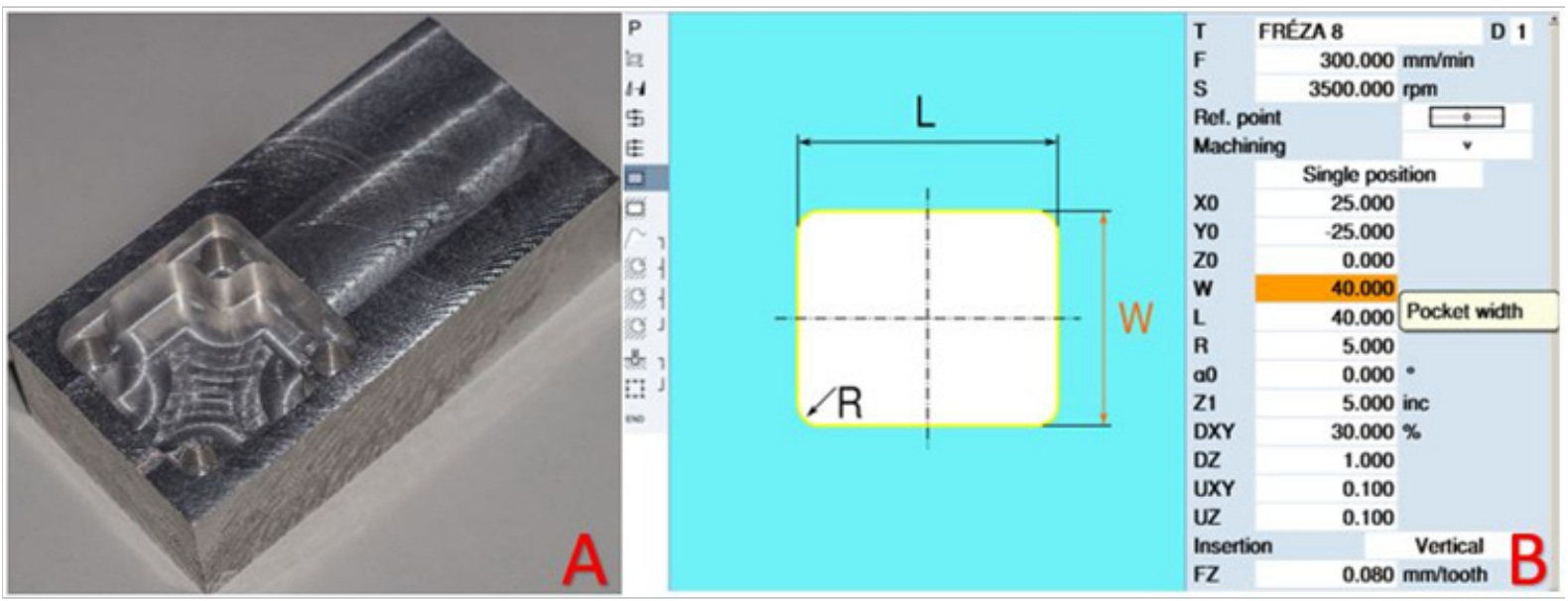

Fig. 4. Second component and dimensions of regular pocket 


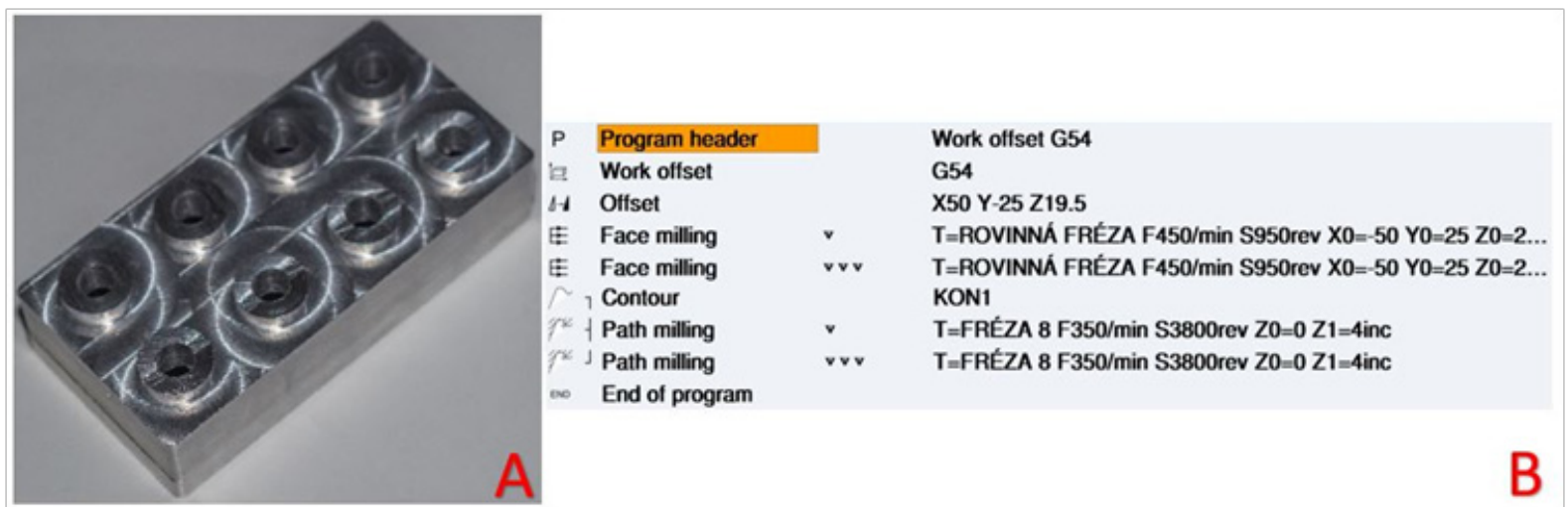

Fig. 5. Third components and NC program with defined contour for milling of spigots

between ISO programing and CAM programing (Chapter Comparison of efficincy between types of programming).

\section{COMPARISON OF EFFICINCY BETWEEN TYPES OF PROGRAMMING}

Four systems were chosen for a comparison of the effectiveness of creation of NC programs. Specifically, Sinumerik 840D and Sinumerik Operate 840D SL, which are part of the training interface WinNC from EMCO Group and two CAD/CAM systems Edgecam 2013 and PTC Creo 2 (Both CAD/CAM systems are used on DAPS).

It is necessary to consider a few facts at comparison between systems:

- appropriateness of the system - shape complexity of components,

- knowledge and skills of the operator or programmer,

- limits of the system - it can influence the functionality of the final $\mathrm{NC}$ program

- step of generating NC program (within the $\mathrm{CAD} / \mathrm{CAM}$ - model, design, code generation optimization program).

Based on these facts, two comparative methods were selected:

- The time required for preparation of the $\mathrm{NC}$ program.

- The number of steps needed to create the NC program.

\section{The time required for preparation of the NC program}

The comparison was made in the two groups. In first group ISO programing and workshop programing were compared, so workshop pro- graming can be used as a replacement for ISO programing.

From table (Table 1) and graph (Fig. 6), it can be seen that the system of workshop programming needs less time for NC program preparation. From the perspective of the knowledge of the ISO code Sinumerik Operate 840D $\mathrm{SL}$ is less demanding for an operator than Sinumerik 840D. Second comparison is a comparison between workshop programing and CAD/ CAM systems.

In Figure 7 it can be seen that CAD/CAM system Edgecam allows a programmer to create $\mathrm{NC}$ program faster, but it requires greater demands on the knowledge and experience of programmer.

\section{The number of steps needed to create the NC program}

This comparison compares the number of steps required to create NC program. (Initial state - draft of the parts). Comparison contains of the workshop programming and CAD/CAM systems Edgecam 2013 and Creo 2.0. Principle of creating $\mathrm{NC}$ program, for all programming methods, is consisted of the same steps as: setting the zero point, face milling, drilling holes, roughing and finishing operations.

A comparison between workshop programming and CAD/CAM systems (Fig. 7 and Tab. 2)

Table 1. Time for preparation NC programs in Sinumerik Operate and Sinumerik 840D

\begin{tabular}{|c|c|c|c|}
\hline Component & $\begin{array}{c}\text { Sinumerik } \\
840 \mathrm{D}\end{array}$ & $\begin{array}{c}\text { Sinumerik } \\
\text { Operate } \\
840 \mathrm{D} \mathrm{SL}\end{array}$ & Difference \\
\hline 1. & $30 \mathrm{~min}$ & $21 \mathrm{~min}$ & $10 \mathrm{~min}$ \\
\hline 2. & $22 \mathrm{~min}$ & $10 \mathrm{~min}$ & $12 \mathrm{~min}$ \\
\hline 3. & $40 \mathrm{~min}$ & $25 \mathrm{~min}$ & $15 \mathrm{~min}$ \\
\hline
\end{tabular}




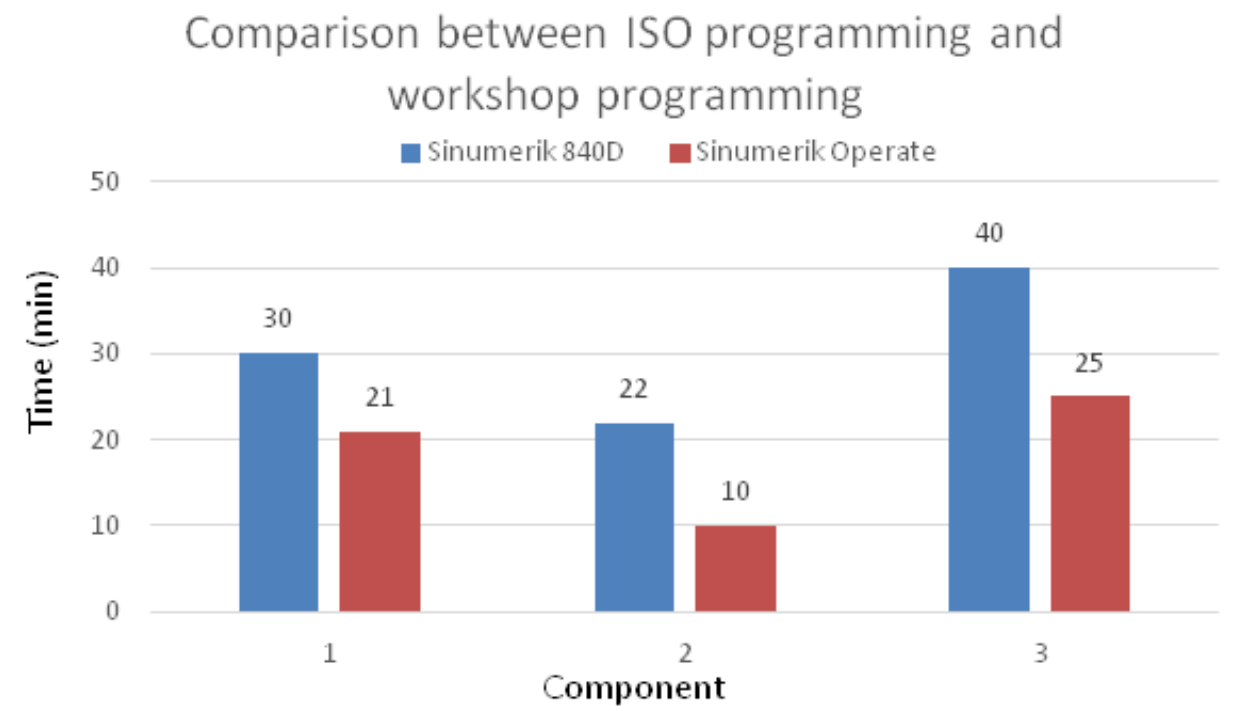

Fig. 6. Comparison between ISO programming and workshop programming on three experimental components

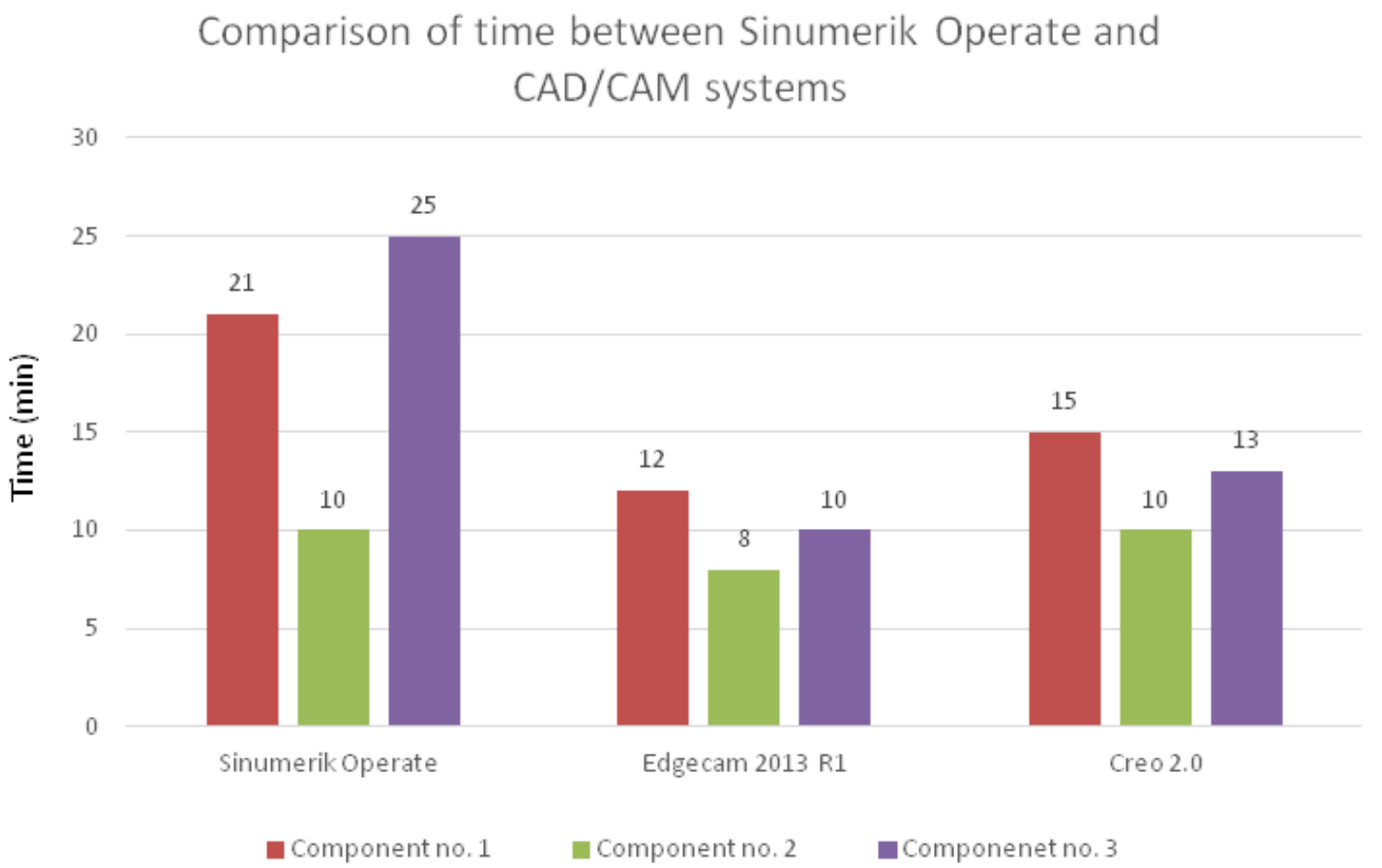

Fig. 7. Comparison of time between Sinumerik Operate 840D and CAD/CAM systems

illustrates the difference in the preparation of the $\mathrm{NC}$ program with regard to the degree of chosen systems but it disregarded shape-complexity of components. It is also needed to take into consideration the level difficulty of working with $\mathrm{CAD} / \mathrm{CAM}$ systems. Although work in CAD/ CAM systems Creo 2.0 and Edgecam required less time (Fig. 7) for preparing the NC program, these systems increase the demands on the programmer, compared to the workshop programming Sinumerik Operate 840D SL, which can use the operator of the machine tool.

\section{CONCLUSIONS}

The results include verification of the control system Sinumerik Operate 840D SL for the production of components. During creation of NC programs by using workshop programing Sinumerik Operate 840D SL some drawbacks have been found. These drawbacks have influence the development of $\mathrm{NC}$ programs and they must be considered in the course of work with system.

The main weaknesses include missing cycle Spigot from menu Contour milling and also less 
Table 2. Number of steps required to create NC programs

\begin{tabular}{|l|c|c|c|}
\hline \multicolumn{1}{|c|}{ Steps } & Operate & EdgeCam & $\begin{array}{c}\text { Creo } \\
2.0\end{array}$ \\
\hline Creation of model & - & 1 & 1 \\
\hline $\begin{array}{l}\text { Creation/Setting of work- } \\
\text { piece }\end{array}$ & 1 & 1 & 1 \\
\hline Setting of zero point & 1 & 1 & 1 \\
\hline Setting of fixture & - & 1 & 1 \\
\hline $\begin{array}{l}\text { recognition of shapes/ } \\
\text { contours }\end{array}$ & 1 & 1 & 1 \\
\hline $\begin{array}{l}\text { Setting of cycles/ } \\
\text { operations }\end{array}$ & 1 & 1 & 1 \\
\hline Simulation & 1 & 1 & 1 \\
\hline $\begin{array}{l}\text { Selection of } \\
\text { prosprocesor }\end{array}$ & - & 1 & 1 \\
\hline $\begin{array}{l}\text { Generation of NC } \\
\text { program }\end{array}$ & - & 1 & 1 \\
\hline $\begin{array}{l}\text { Optimization of NC pro- } \\
\text { gram }\end{array}$ & - & 1 & 1 \\
\hline Transfer of NC program & 11 & 11 \\
\hline Number of steps & & 1 \\
\hline
\end{tabular}

number of available cycles compared Sinumerik Operate 4.5 by Siemens AG. After consultation with the distributor of the EMCO machines it has been found that the current version of Sinumerik Operate 840D SL does not support same cycles. The limited number of cycles available may have an impact on the preparatory times mentioned in chapter Comparison of efficincy between types of programming. These drawbacks can be eliminated with additional system updates.

After verification of workshop programing Sinumerik Operate 840D SL during producing of experimental components, were defined the current system capabilities. Also they were specified current limits of system for further experimental research thesis and projects. The comparison between different types of programming and systems shows the differences in creation of NC programs. The comparison of results points to a principle and possibilities of this type of programming.

\section{Acknowledgement}

This article was made under support projects KEGA 037ŽU-4/2014 - The Development of Complex Interactive Educational Portal for Support the Teaching of CNC Production Machines Programming.

\section{REFERENCES}

1. Císar, M.: Diagnosis of equipments. In: Mechanization and automation equipment for processing. Cluj-Napoca: Publishing House Alma Mater, 2015, 209-240.

2. Náprstková, N: Students connecting to production problems resolutions in CAD/CAM area. In: 9th International Scientific Konference - Engineering for rural development 2010, Jelgava, 2728.5.2010, 310 .

3. Čuboňová, N.: Computer aided programming of CNC machines. (Počítačová podpora programovania CNC strojov - in Slovak). EDIS ŽU Žilina, 2012, 115.

4. Litvaj, I.; Stančeková, D.: Knowledge management embedment in company, knowledge repositories, knowledge management significance and usage in company. In decision - making. Procedia Economics and Finance, 2015.

5. Legutko, S.: Materials for Cutting Tools. In. Development of Mechanical Engineering as a Tool for the Enterprise Logistics progress, published by Poznan University of Technology, Poznan 2006, 33-49.

6. Rudawska, A.: Selected aspects of the construction adhesive connections homogeneous and hybrid. (Wybrane zagadnenia konstruowania polaczen nadhezyjnych jednorodnych i hybrydowych - in Polish), Politechnika Lubelska, 2013, 26-6, 181.

7. Stuchlý, V.; Poprocký, R.: Údržba strojov a zariadení, 1. vyd. Žilina: Žilinská univerzita, 2013. 359.

8. Čuboňová, N.; Náprstková, N. NC Verification, Machine Simulation and NC Optimization in CAM Systems. In: 1st edition Advanced Methods and Trends in Production Engineering. Scientific Bulletin, Serie C, Volume XVIII, 5th edition The International Meeting of the Carpathian Region specialists in the field of Gears, Baia Mare, Romania, May 21-22, 2004, 57-62.

9. Kapustová, M.; Görögová, I.: Application of computer simulation for optimization of technological parameters of precision forging. Tehnički Vjesnik - Technical Gazette 2016, 23, 2, 357-361.

10. Rengevič, A.; Kumičakova, D.: New possibilities of robot arm motion simulation. Communications: scientific letters of the University of Žilina. 2016, 18, 1A, 81-86.

11. Kumicakova, D.; Jakubcik, M.: Specialised robotic hand designing and object grasping simulation. Applied Mechanics and Materials, vol. 282/2013, 90-98. 